Full-length article

\title{
Ouabain at pathological concentrations might induce damage in human vascular endothelial cells
}

\author{
Yan-ping REN ${ }^{1}$, Ruo-wen HUANG, Zhuo-ren LÜ \\ Geriatric-Cardiovascular Department, First Hospital of Xi'an Jiaotong University, Xi'an 710061, China
}

\section{Key words}

ouabain; endothelium; hypertension; potassium channels

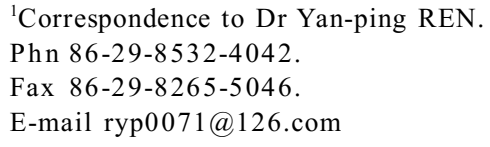

Received 2005-04-14

Accepted 2005-08-05

doi: $10.1111 /$ j.1745-7254.2006.00244.x

\begin{abstract}
Aim: To examine the time- and dose-dependent effects of ouabain on human umbilical vein endothelial cells (HUVEC) in vivo, and the changes in aortic endothelium and the different expression levels of Kv4.2 in vitro. Methods: The proliferation of HUVEC and cell death were determined by 3-(4,5-dimethylthiazol-2-yl)2,5-diphenyl- $2 \mathrm{H}$-tetrazolium bromide (MTT) assay, the incorporation of $\left[{ }^{3} \mathrm{H}\right] \mathrm{TdR}$, trypan blue staining, and lactate dehydrogenase (LDH) release. The response of endothelial cells to ouabain was explored with a complementary DNA microarray and a candidate gene was found. "Ouabain-sensitive" hypertensive rats were established by chronic administration of ouabain. Changes in the aortic endothelium were observed by electron microscopy, and the expression level of Kv4.2 in different animals was studied by using real-time quantitative reverse transcription-polymerase chain reaction (RT-PCR). Results: Ouabain stimulated the proliferation of HUVEC at physiological concentrations $(0.3-0.9 \mathrm{nmol} / \mathrm{L})$. Ouabain at pathological concentrations $(0.9-1.8 \mathrm{nmol} / \mathrm{L})$ inhibited proliferation and induced cell death. mRNA profile analysis indicated that 340 genes were differentially expressed after ouabain treatment: 145 were upregulated, of which 6 were upregulated significantly, including KCND2 (encoding the potassium voltagegated channel shal-related subfamily member 2 ). The upregulated genes were mainly related to cell metabolism and transcription. In ouabain-sensitive hypertensive rats, the aortic endothelium was damaged and Kv4.2 (coded by KCND2) was over-expressed. Conclusion: The physiological role of ouabain in HUVEC might involve the control of growth and metabolism. Ouabain at pathological concentrations might affect the structure and function of the vascular endothelium by modification of expression of the KCND2 gene, and participate vascular remodeling in hypertension.
\end{abstract}

\section{Introduction}

Ouabain and other cardiac glycosides have been known as specific inhibitors of sodium pumps and purified $\mathrm{Na}^{+} / \mathrm{K}^{+}$ATPases ever since the very first observations of inhibition of the sodium pumps of red blood cells. As an endogenous mammalian counterpart to cardiac glycosides and an inhibitor of sodium pumps, it regulates the body fluid volume balance, in addition to urine sodium extraction and vasoconstrictive tone, thus playing an important role in the patho- genesis of hypertension and some other cardiovascular disorders $^{[1]}$. Although ouabain is known to induce hypertension, the mechanism by which this cardiac glycoside affects blood pressure and vascular remodeling is uncertain. In 1976, Ross proposed that chronic hypertension might induce endothelium damage, and result in vascular remodeling and target organ dysfunction, and since then the role of endothelium in cardiovascular diseases has been confirmed. The physiological and pathophysiological importance of ouabain in the vascular endothelium is not clear. The objective of the 
present study was to investigate: (i) the effect of ouabain at different concentrations on human umbilical vascular endothelial cells (HUVEC); (ii) the mechanism by which ouabain exerts its effect; and (iii) its potential role in hypertensive vascular remodeling.

\section{Materials and methods}

Cell cultures Ouabain was from Sigma (St Louis, MO, USA). HUVEC were cultured in RPMI-1640 medium (Gibco, Logan, Utah, USA) supplemented with 15\% heat-inactivated fetal calf serum (FCS), endothelial cell growth factor $3 \mathrm{mg} / \mathrm{mL}$, penicillin $200 \mathrm{U} / \mathrm{mL}$, streptomycin $100 \mathrm{mg} / \mathrm{mL}$, and $L$-glutamine $20 \mathrm{mmol} / \mathrm{L}$, and incubated in a humidified atmosphere with $5 \% \mathrm{CO}_{2}$ at $37^{\circ} \mathrm{C}$. At passage $2-3$, the confluent HUVEC were used for experiments. HUVEC were added to a 96-well multiplate with $5 \times 10^{3}$ cells in each well, and incubated with RPMI1640 medium without FCS to preserve quiescence. Twentyfour hours later the medium was changed with RPMI-1640 medium supplemented with FCS.

Cell morphology analysis Cell morphology was evaluated by phase-contrast microscopy without preliminary fixation. To estimate cell attachment, cells growing in 6-well plates in the absence or presence of ouabain were washed 4 times with phosphate-buffered saline. Next, the cells were harvested with $0.05 \%$ trypsin. After fixation, dehydration, embedding, and sectioning using routine methods, the cells were observed with a Hitachi H600 transmission electron microscope (Hitachi, Tokyo, Japan).

Cell viability measurement Cell viability was measured by using a colorimetric assay with 3-(4,5-dimethylthiazol-2yl)-2,5-diphenyl-2H-tetrazolium bromide(MTT). Briefly, the cells were incubated with ouabain at different concentration $(0.3,0.6,0.9,1.2,1.8,10,100,1000 \mathrm{nmol} / \mathrm{L})$ and for different durations $(0.5,1,2,4,8,16,24,48 \mathrm{~h})$, respectively. Then the $0.5 \mathrm{mg} / \mathrm{mL}$ MTT solution (Sigma) was added to each well and the cells were incubated for a further $4 \mathrm{~h}$ at $37^{\circ} \mathrm{C}$. After the cells were washed 3 times with phosphate-buffered saline (PBS; pH 7.4), the insoluble formazon product was dissolved by incubation with $150 \mu \mathrm{L} \mathrm{Me} 2 \mathrm{SO}$ for $15 \mathrm{~min}$. The absorbance $(A)$ of each well was measured on an enzymelinked immunosorbent assay (ELISA) micro-plate reader at $490 \mathrm{~nm}$. The cells without ouabain treatment served as controls. Each experiment was performed in quadruplicate. The proliferation rate was calculated as follows: $\left(A_{\text {Exp }} / A_{\text {Control }}-1\right)$ $\times 100 \%$.

Trypan blue exclusion assay HUVEC were incubated in the absence or presence of ouabain 0.3 or $1.8 \mathrm{nmol} / \mathrm{L}$ for $8 \mathrm{~h}$. Both attached and floating cells were combined and stained with $0.2 \%$ trypan blue. Viable cells were counted and expressed as a proportion of cells without ouabain treatment.

Lactate dehydrogenase assay HUVEC were incubated in RPMI-1640 supplemented with FCS containing ouabain 0.3 or $1.8 \mathrm{nmol} / \mathrm{L}$ for $8 \mathrm{~h}$. A $0.5 \mathrm{~mL}$ aliquot of supernatant was transferred to the same volume of $1 \%$ Triton X-100, and attached cells were lysed with $500 \mu \mathrm{L} 0.5 \%$ Triton X-100 at room temperature for $15 \mathrm{~min}$. Subsequently, aliquots $(300 \mu \mathrm{L}$ supernatant or lysate) were transferred into $2 \mathrm{~mL}$ buffer containing Tris- $\mathrm{HCl} 50 \mathrm{mmol} / \mathrm{L}$ (pH 7.4), $\mathrm{KCl} 50 \mathrm{mmol} / \mathrm{L}$, reduced $\beta$-nicotinamide-adenine dinucleotide (NADH) $0.075 \mathrm{mmol} / \mathrm{L}$, and sodium pyruvate $1 \mathrm{mmol} / \mathrm{L}$. The kinetics of NADH degradation were monitored with a SPEX FluoroMax spectrofluorimeter (Edison, NJ, USA) at $\lambda_{\mathrm{ex}}=349 \mathrm{~nm}$ and $\lambda_{\mathrm{em}}=420 \mathrm{~nm}$ (slits 4 and $20 \mathrm{~nm}$, respectively). The total cellular lactate dehydrogenase (LDH) activity was determined from the activity of the lysate plus the activity of the supernatant. The percentage of LDH released was expressed as the proportion of LDH released into medium as compared with the total amount of LDH.

$\left[{ }^{3} \mathbf{H}\right]$ Thymidine incorporation $\left[{ }^{3} \mathrm{H}\right] \mathrm{TdR}\left(3.7 \times 10^{4} \mathrm{~Bq} /\right.$ well $)$ was added to every well in the presence of ouabain to observe the effect of ouabain at different concentrations on $\left[{ }^{3} \mathrm{H}\right]-\mathrm{TdR}$ intake. Cells were collected on fiberglass filler paper by using an automatic multi-head cell collector before being rinsed and fixed. Cells were then dried at $80{ }^{\circ} \mathrm{C}$, and then scintillation liquid was added. $\left[{ }^{3} \mathrm{H}\right]$ Thymidine incorporation was measured by using a liquid scintillation analyzer.

Gene chip detection The BiostarH-80s gene chip with 8464 spots was used (Shanghai Biostar Genechip, Shanghai, China). After incubation with ouabain $0.3 \mathrm{nmol} / \mathrm{L}$ for $2 \mathrm{~h}$, total RNA of the endothelial cells was extracted according to the original single-step extraction procedure of Chomczynski et $a l^{[2]}$. Messenger RNAs were purified by using an Oligotex dT mRNA Midi kit (Qiagen, Carlsbad, CA, USA). The fluorescent cDNA probes were prepared by reverse transcription of the isolated mRNA and then purified according to the method of Schena et $a l^{[3]}$. The RNA samples from the ouabain-free group were labeled with Cy3-dUTPs and those from the ouabain group with Cy5-dUTPs. The two colored probes were then mixed, precipitated with ethanol and dissolved in $20 \mu \mathrm{L}$ of hybridization solution $[5 \times \mathrm{SSC}(0.75 \mathrm{~mol} / \mathrm{L} \mathrm{NaCl}$ and sodium citrate $0.075 \mathrm{~mol} / \mathrm{L}), 0.4 \%$ sodium dodecylsulfate (SDS), $50 \%$ formamide, and $5 \times$ Denhardt's solution $(0.1 \%$ Ficoll, $0.1 \%$ polyvinylpyrrolidone, and $0.1 \%$ bovine serum albumin)]. Microarrays were pre-hybridized with hybridization solution containing denatured salmon sperm DNA 0.5 $\mathrm{mg} / \mathrm{mL}$ at $42{ }^{\circ} \mathrm{C}$ for $6 \mathrm{~h}$. Fluorescent probe mixtures were applied onto the pre-hybridized chip under cover glass. 
Chips were hybridized at $42^{\circ} \mathrm{C}$ for $15-17 \mathrm{~h}$. The hybridized chips were then washed at $60^{\circ} \mathrm{C}$ for $10 \mathrm{~min}$ in solutions of (i) $2 \times \mathrm{SSC}$ and $0.2 \% \mathrm{SDS}$; (ii) $0.1 \times \mathrm{SSC}$ and $0.2 \% \mathrm{SDS}$; and(iii) $0.1 \times \mathrm{SSC}$, respectively, then dried at room temperature. The chips were scanned with a ScanArray 4000 (Packard BioScience, Billerica, MA, USA) at two wavelengths to detect emissions from both $\mathrm{Cy} 3$ and $\mathrm{Cy} 5$. The acquired images were analyzed using ImaGene 3.0 software (BioDiscovery, Inc, Los Angeles, CA). The intensities of each spot at the two wavelengths represented the quantities of Cy3-dUTP and Cy5-dUTP, respectively, hybridized to each spot. Ratios of Cy5 to Cy3 were computed for each location on each microarray.

Established animal model The rats used to establish the animal model were grade II, and the certificate number of the breeder is 08-005. The project was approved by the Animal Experimentation Ethics Committee of Xi'an Jiaotong University. Six-to-ten-week-old male Sprague-Dawley rats (150-200 g) were used for the experiments after being kept in a temperature-controlled room for a week. The rats were randomly assigned to the experimental and control groups. The rats in the former group $(n=52)$ received a maintenance dose of ouabain intraperitoneally. On d 1, a loading dose of $34 \mu \mathrm{g} / \mathrm{kg}$ ip was administered, followed by a dose of 27.8 $\mu \mathrm{g} \cdot \mathrm{kg}^{-1} \cdot \mathrm{d}^{-1}$ ip for an additional 8 weeks every day. The control group $(n=20)$ received vehicle $(0.9 \%$ saline) only. Ouabain was dissolved in sterile saline at a concentration of $20 \mu \mathrm{g} / \mathrm{mL}$ and stored for up to 1 week at $4{ }^{\circ} \mathrm{C}$ in the $\operatorname{dark}^{[4]}$. Systolic blood pressure was recorded with a tail cuff once a week using a heart rate and blood pressure recorder for rats (RBP-1B; China-Japan Clinical Medicine Institute, Beijing, China). The average of 3 recordings was taken as the individual systolic blood pressure. Measurements obtained using this method correlate well with those obtained using the direct cannulation method ${ }^{[5]}$. The 2 groups of animals were kept in the same conditions during the experiment and all were killed after 8 weeks. At that time, tissue samples were collected for experiments.

Electron microscopy Animals were anesthetized with
$20 \%$ urethane ip, and the ascending aorta was then removed. Samples of the aorta were chipped into $1 \mathrm{~mm} \times 1 \mathrm{~mm} \times 1 \mathrm{~mm}$ blocks, and pre-fixed in the glutaraldehyde buffer for $2 \mathrm{~h}$. After dehydration, embedding, and sectioning using routine methods, the sections were observed with a Hitachi H600 transmission electron microscope. The remaining part of the aorta was preserved in liquid nitrogen for reverse transcription-polymerase chain reaction (RT-PCR).

RT-PCR primers and probe design Primers and probes for quantitative RT-PCR were designed and synthesized by the Shanghai Sangon Biological Engineering Technology and Service Co (Shanghai, China). The melting temperature for primers was set at $50-60{ }^{\circ} \mathrm{C}$, but the probe's melting temperature was at least $10{ }^{\circ} \mathrm{C}$ higher. The minimum GC content for the primers and probes was $20 \%-80 \%$, and runs of identical nucleotides were avoided. The strands were between 9 and 40 nucleotides in length.

Quantitative RT-PCR Total RNA was extracted using the Trizol Max kit (Invitrogen, Carlsberg, CA, USA). Fluorescent real-time quantitative RT-PCR was used to determine differences between the model group and control group with respect to $K v 4.2$ mRNA expression levels in the endothelium of the ascending aorta. Expression levels were quantitated using a one-step RT-PCR reaction using the Super Script One-Step RT-PCR kit with Platinum Tag (Invitrogen), following the manufacturer's instructions (with modifications). A total reaction volume consisted of $1 \mu \mathrm{L}$ forward primer, $1 \mu \mathrm{L}$ reverse primer, $1 \mu \mathrm{L}$ fluorescent probe, $1 \mu \mathrm{L}$ RT/Platinum Taq Mix and $4 \mu \mathrm{L}$ total RNA was made up to $50 \mu \mathrm{L}$ with RNasefree water. One-step RT-PCR amplification was performed in the ABI Prism 7700 Sequence Detection System (Perkin-Elmer, Foster City, CA). Thermal cycling conditions were as follows: $94{ }^{\circ} \mathrm{C}$ for $5 \mathrm{~min}$, followed by 50 cycles of $94^{\circ} \mathrm{C}$ for $30 \mathrm{~s}, 56^{\circ} \mathrm{C}$ for $30 \mathrm{~s}$ and $72{ }^{\circ} \mathrm{C}$ for $30 \mathrm{~s}$, then $72^{\circ} \mathrm{C}$ for $5 \mathrm{~min}$, and finally the reaction was held at $4{ }^{\circ} \mathrm{C}$. The housekeeping gene $G A P D H$ was used to normalize samples to remove the impact of any variations in RNA loading.

Statistical analysis Data are expressed as mean \pm SEM.

Table 1. Primers for Kv4.2 and GAPDH.

$$
\text { Gene name } \quad \text { Primer }
$$

Kv4.2 PCR

GAPDH PCR
Forward primer: 5'-GCC TTC GTT AGC AAA TCT GGA TC-3' Reverse primer: 5'-CAC TTC CAT GCA GCT TTC TTC AA-3' Probe: 5'-FAM-CG AGA CAA CAC CAC CAC CTG CTT-CAC-TAMRA-3' Forward primer 5'-TGG TCT ACA TGT TCC AGT ATG ACT-3' Reverse primer 5'-CGT TTG ATG TTA GCG GGA TCT C-3' Probe: 5'-FAM-AC GGC AAG TTC AAC GGC AC GTC AA-TAMRA-3' 
Difference between groups before and after treatment were tested by using the paired $t$-test, and comparisons between groups were carried out using Student's $t$-test. $P<0.05$ was considered significant.

\section{Results}

Effect of ouabain on morphology of HUVEC After HUVEC were treated with ouabain $0.3 \mathrm{nmol} / \mathrm{L}$ for $8 \mathrm{~h}$, the morphology of HUVEC was similar to that of the control group. But ouabain $1.8 \mathrm{nmol} / \mathrm{L}$ induced apoptosis in endothelial cells. Cell swelling and apoptotic bodies were observed (Figure 1).

Effect of ouabain on the proliferation of HUVEC Treatment with ouabain at $0.3-0.9 \mathrm{nmol} / \mathrm{L}$ for $2 \mathrm{~h}$ stimulated cell proliferation (Figure 2). However, ouabain at a concentration of $1.8 \mathrm{nmol} / \mathrm{L}$ for $0.5 \mathrm{~h}$ induced some cell proliferation (Figure 3B), and then showed an anti-proliferative effect after long-term treatment. In contrast, compared with the control group, cell proliferation increased by $50 \%$ after treatment with ouabain at a concentration of $10 \mathrm{nmol} / \mathrm{L}$. With an increase of the concentration of ouabain $(100,1000 \mathrm{nmol} / \mathrm{L})$, the proliferation rate gradually decreased (Figure 2).

Ouabain at concentrations of $0.3 \mathrm{nmol} / \mathrm{L}$ and $10 \mathrm{nmol} / \mathrm{L}$ stimulated, and ouabain at a concentration of $1.8 \mathrm{nmol} / \mathrm{L}$ inhibited HUVEC proliferation in a time-dependent manner (Figure 3).

After 8-h treatment with ouabain $0.3 \mathrm{nmol} / \mathrm{L}$, cell viability and LDH release did not change $(P>0.05)$, but $\left[{ }^{3} \mathrm{H}\right]$ thymidine incorporation increased $(P<0.01)$ compared with the control group. Cell viability and $\left[{ }^{3} \mathrm{H}\right]$ thymidine incorporation decreased and LDH release increased after 8-h treatment with ouabain $1.8 \mathrm{nmol} / \mathrm{L}(P<0.01$; Figure 4$)$.

Effect of ouabain on the gene expression profile Scatter plots and two-color fluorescence after hybridization indicated that 340 genes were expressed differently in response to ouabain treatment. One hundred and forty-five genes were upregulated, among which 6 genes were markedly upregulated, including $K C N D 2$ gene. The upregulated genes were mainly related to cell metabolism and transcription (Table 2 ). We focused on the KCND2 gene and carried out a further experiment in relation to it.

Effects of continued infusion of ouabain on systolic blood pressure In the first 4 weeks the SBP of all rats increased, accompanied by an increase in weight; however, there was no significant difference between the ouabain group and the control group. From the fifth week, the SBP of 45 of the 52 rats in the ouabain group began to increase. Six weeks later the SBP of the 45 rats were markedly higher than those of the control group, which received normal saline $(142.3 \pm 8.2 \mathrm{mmHg}$

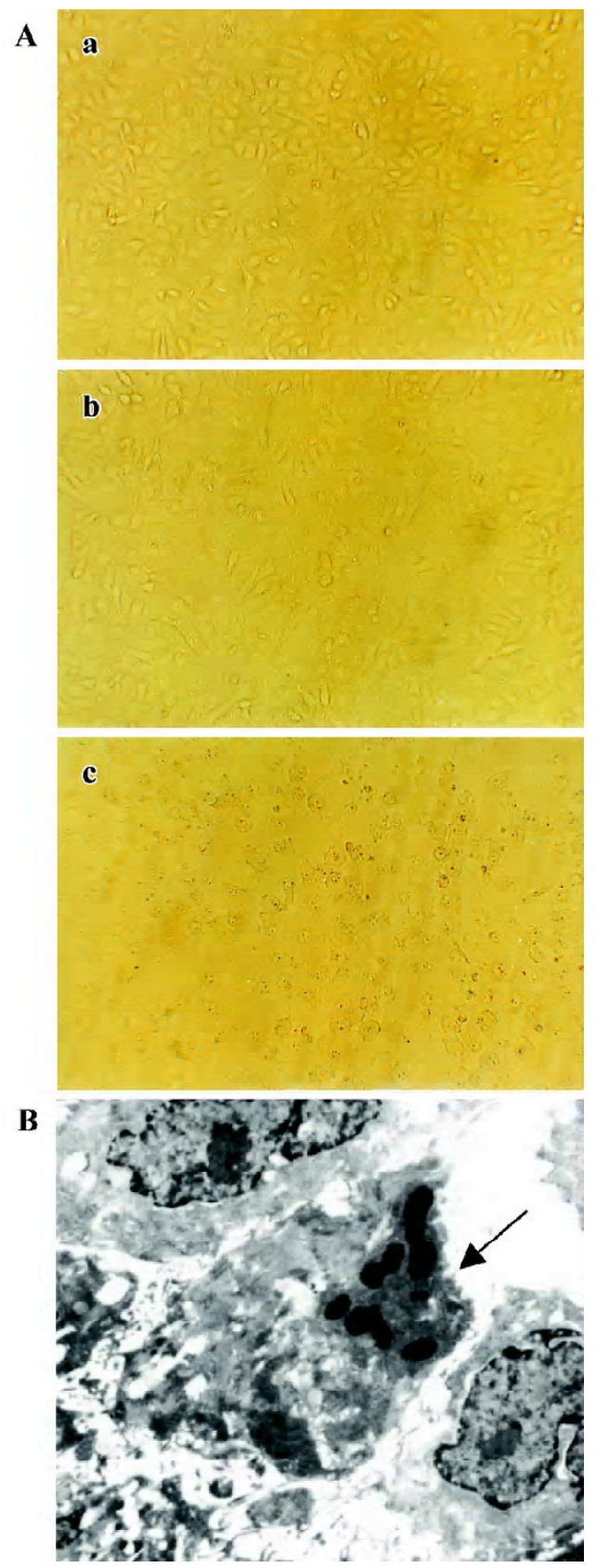

Figure 1. Effect of ouabain on the morphology of human umbilical vein endothelial cells (HUVEC). (A) Phase-contrast micrograph of HUVEC. (a) Control cells. (b) Cells treated with ouabain $0.3 \mathrm{nmol} / \mathrm{L}$ for $8 \mathrm{~h}$. (c) Cells treated with ouabain $1.8 \mathrm{nmol} / \mathrm{L}$ for $8 \mathrm{~h}(\times 100)$. (B) Electromicrograph of HUVEC treated with ouabain $1.8 \mathrm{nmol} / \mathrm{L}$ for $8 \mathrm{~h}$. The arrow indicates the formation of apoptotic bodies. $\times 5000$.

vs $123.4 \pm 5.4 \mathrm{mmHg} ; P<0.01]$. These 45 rats were designated "ouabain-sensitive" (OS) rats. In the remaining 7 rats in the ouabain group, the SBP did not increase, and these 7 rats were designated "ouabain-resistant" (OR) rats (Figure 5). 


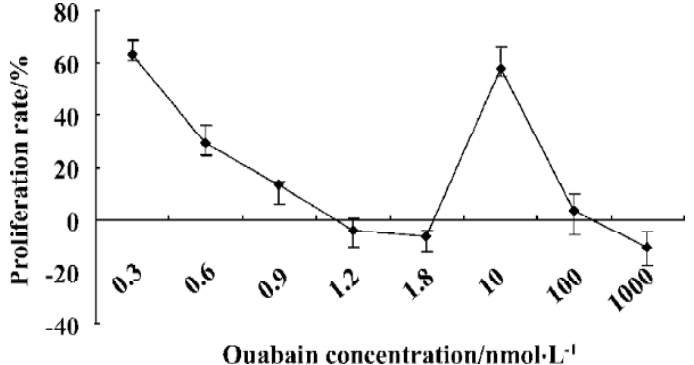

Figure 2. The concentration-dependent effect of ouabain on proliferation of human umbilical vein endothelial cells (HUVEC). HUVEC were incubated with ouabain for 2 h. $n=4$. Mean \pm SEM.
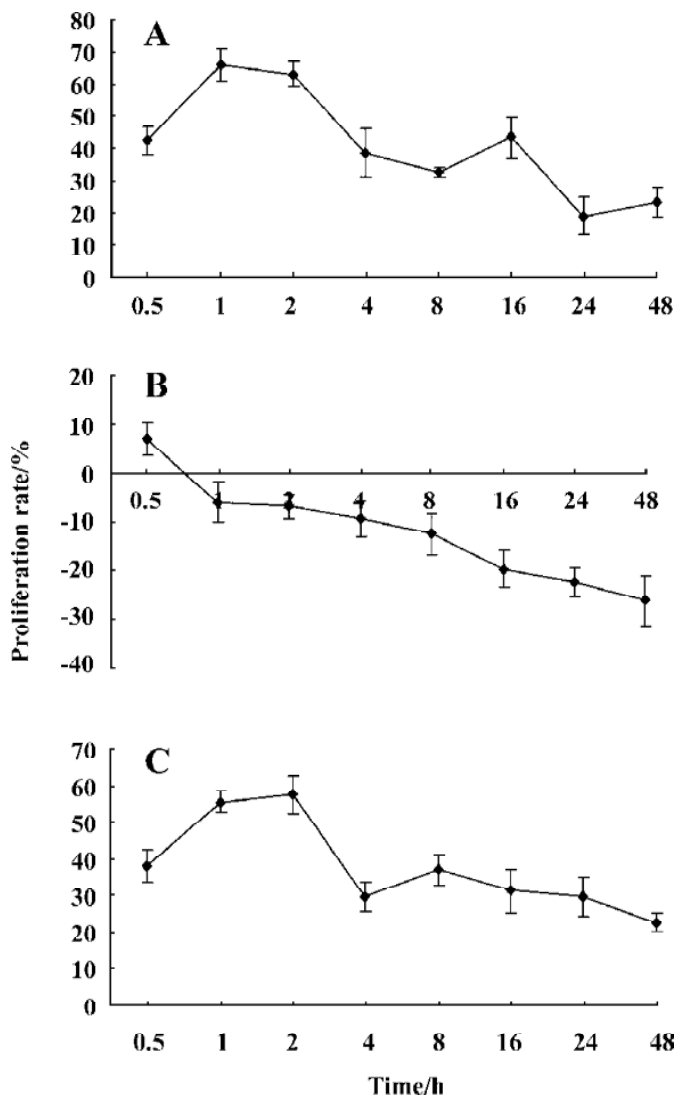

Figure 3. The time-dependent effect of ouabain on human umbilical vein endothelial cells (HUVEC). (A) Ouabain $0.3 \mathrm{nmol} / \mathrm{L}$. (B) Ouabain $1.8 \mathrm{nmol} / \mathrm{L}$. (C) Ouabain $10 \mathrm{nmol} / \mathrm{L}$. $n=4$. Mean \pm SEM.

\section{Changes in aortic endothelium in OS and OR rats In OS} rats, the structure of the aortic endothelium was damaged and the nuclei were depleted. In OR rats, the aortic endothelium was integrated, the nuclei were clear, and the endothelial cells were tightly linked to the internal elastic membrane (Figure 6).

Effect of ouabain on $K v 4.2$ gene expression in OS and OR rats $K v 4.2$ expression was markedly higher in OS rats than in OR and control rats $(P<0.01$; Figure 7$)$.
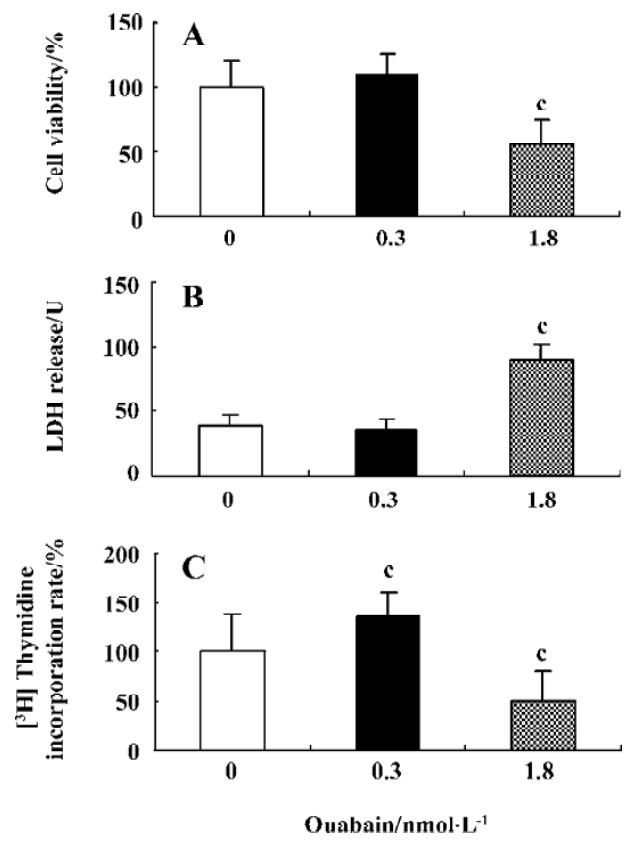

Figure 4. Effect of an 8-h treatment with ouabain at concentrations of 0.3 and $1.8 \mathrm{nmol} / \mathrm{L}$ on cell viability (A), $\mathrm{LDH}$ release (B), and $\left[{ }^{3} \mathrm{H}\right]$ thymidine incorporation $(\mathrm{C})$ of human umbilical vein endothelial cells (HUVEC). The cell viability and $\left[{ }^{3} \mathrm{H}\right]$ thymidine incorporation rate of the control group was $100 \% . n=4$. Mean \pm SEM. ${ }^{c} P<0.01$ vs control $(0 \mathrm{nmol} / \mathrm{L})$.

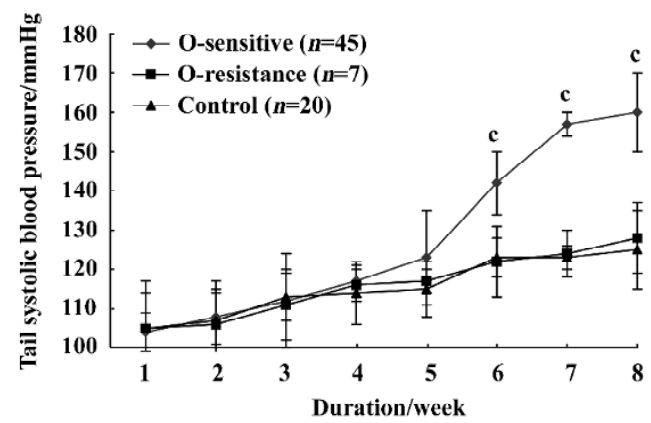

Figure 5. Effects of continued infusion of ouabain on tail systolic blood pressure. $n=4$. Mean \pm SEM. ${ }^{\mathrm{c}} P<0.01$ vs control.

\section{Discussion}

Ouabain is one of the most highly hydroxylated, water soluble and potent cardiac glycosides. It was recognized as the primary active component of Masai arrow poison more than 100 years ago by the French anthropologist Arnaud. Recent work has shown that ouabain (or closely related isomers) is present in the human circulation ${ }^{[6]}$.

The effect of ouabain as a sodium pump $\left(\mathrm{Na}^{+} / \mathrm{K}^{+}\right.$-ATPase $)$ inhibitor is mediated by cell depolarization and $\left[\mathrm{Na}^{+}\right]_{\mathrm{i}}$ elevation, resulting in activation of voltage-gated $\mathrm{Ca}^{2+}$ chan- 
Table 2. Effect of ouabain on the gene expression profile of human umbilical vein endothelial cells.

\begin{tabular}{|c|c|c|}
\hline GenBank number & Gene name & $\mathrm{Cy} 5 / \mathrm{Cy} 3$ ratio \\
\hline NM_005463 & Homo sapiens heterogeneous nuclear ribonucleoprotein D-like (HNRPDL), transcript variant, mRNA & 0.248 \\
\hline NM_005216 & Homo sapiens dolichyl-diphosphooligosaccharide-protein glycosyltransferase (DDOST), mRNA & 0.249 \\
\hline NM_001654 & Homo sapiens v-raf murine sarcoma 3611 viral oncogene homologue (ARAF1), mRNA & 0.259 \\
\hline AF020544 & Homo sapiens inactive palmitoyl-protein thioesterase-2i (PPT2) mRNA, complete cds & 0.277 \\
\hline AK027607 & Homo sapiens cDNA FLJ14701 fis, clone NT2RP3000109, weakly similar to P54 protein precursor & 0.290 \\
\hline NM_002828 & Homo sapiens protein tyrosine phosphatase, non-receptor type 2(PTPN2), mRNA & 0.301 \\
\hline NM_005744 & Homo sapiens ariaden (Drosophila) homologue, ubiquitin-conjugating enzyme E2-binding protein, mRNA & 0.310 \\
\hline АB 023222 & Homo sapiens mRNA for KIAA1005 protein, partial cds & 0.317 \\
\hline AL133108 & Homo sapiens mRNA; cDNA DKFZp566M0947 (from clone DKFZp566m0947) & 0.328 \\
\hline NM_006432 & Homo sapiens epididymal secretory protein (19.5JD) (HE1), mRNA & 0.331 \\
\hline NM_014952 & Homo sapiens KIAA0945 protein (KIAA0945), mRNA & 0.332 \\
\hline NM_000824 & Homo sapiens glycine receptor, beta (GLRB), mRNA & 3.001 \\
\hline NM_012281 & Homo sapiens potassium voltage-gated channel, Shal-related subfamily, member 2 (KCND2), mRNA & 3.148 \\
\hline NM_004041 & Homo sapiens arrestin, beta 1 (ARRB1), transcript variant $1, \mathrm{mRNA}$ & 3.358 \\
\hline NM_006567 & Homo sapiens phenylalanine-tRNA synthetase (FARS1),nuclear gene encoding mitochondrial protein, mRNA & 3.367 \\
\hline NM_012227 & Homo sapiens pseudoautosomal GTP-binding protein-like (PGPL), mRNA & 4.022 \\
\hline AF092137 & Homo sapiens FK506-binding protein mRNA, complete cds & 6.451 \\
\hline
\end{tabular}
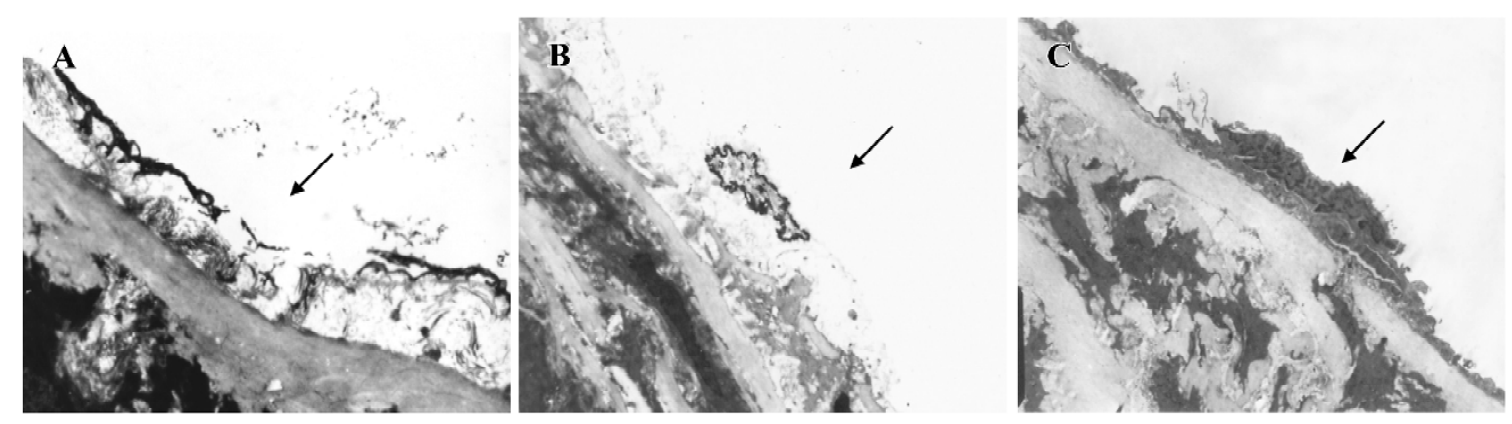

Figure 6. Changes in a ortic endothelium in ouabain-sensitive (A), ouabain-resistant (B) and control (C) rats. $\times 5000$.

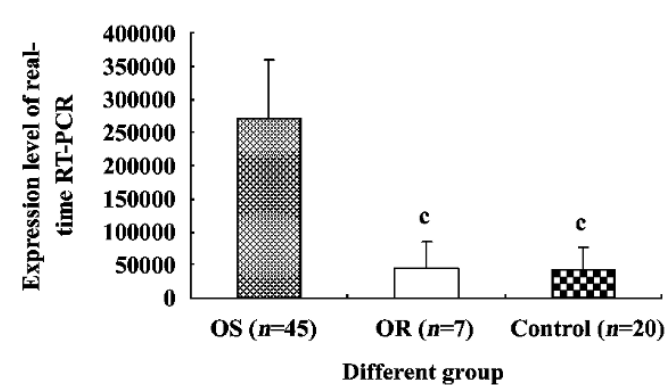

Figure 7. The effect of ouabain on $K v 4.2$ gene expression in ouabain sensitive (OS) and ouabain resistance (OR) rats. Mean $\pm \mathrm{SEM}$. ${ }^{\mathrm{c}} P<0.01$ vs the OS group.

nels and the electrogenic $\mathrm{Ca}^{2+} / 3 \mathrm{Na}_{\mathrm{i}}^{+}$exchanger ${ }^{[7]}$. The effect of ouabain on cell survival is tissue-specific ${ }^{[8]}$. Twentyfour hours of treatment with ouabain detaches and kills
Madin-Darby canine kidney (MDCK) epithelial cells; however, 2 to $4 \mathrm{~d}$ treatment with ouabain does not affect the survival of renal epithelial cells from Rhesus monkeys, human lymphocytes or vascular smooth muscle cells (VSMC) from the rat aorta.

Ouabain has been known to act as a hormone and is possibly involved in the pathogenesis of hypertension ${ }^{[9]}$. To investigate the mechanism that is involved in the vascular remodeling that occurs during hypertension, we studied the effects of ouabain on HUVEC in culture. We found that ouabain at physiological concentrations $(0.3-0.9 \mathrm{nmol} / \mathrm{L})$ stimulated the proliferation of HUVEC. However, at pathological concentrations $(0.9-1.8 \mathrm{nmol} / \mathrm{L})$, cell death was induced, including the swelling phenomenon and appearance of apoptosis bodies. As Xiao et al suggested, the neuronal death associated with ouabain treatment consisted 
of concurrent apoptotic and necrotic components ${ }^{[10]}$. The proteome analysis indicated that ouabain treatment led to overexpression of numerous soluble and hydrophobic cellular proteins ${ }^{[11]}$. The results of mRNA profile analysis indicated that most of the upregulated genes were related to signal transduction and metabolism. The candidate genes were screened from the abovementioned genes and analyzed further.

We found that the protein kinase gene (NM_002737) and protein phosphatase genes (NM_014225 and $\left.N M \_002719\right)$ were upregulated. These 2 genes regulate signal transduction by catalysis phosphorylation and dephosphorylation. The protein kinase and protein phosphatase act on tyrosine, serine, and threonine, related to cell proliferation and differentiation ${ }^{[12,13]}$. DAPK1 (death-associated protein) (NM 004938), a calcium/calmodulin-dependent serine/threonine kinase, exerts apoptotic effects by suppressing integrin functions and integrin-mediated survival signals, and activating a p53-dependent apoptotic pathway $^{[14]}$. According to these early responsive gene (ERG), ouabain mediates the expression of downstream genes, and makes the endothelial cells in normal metabolism condition. Also, ouabain upregulates many transcription genes, such as tumor necrosis factor receptor-associated factor family member-associated NF-KB activator (TANK) (NM_004180),

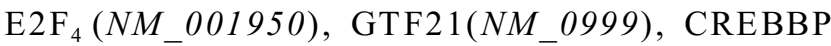
(NM_004380) and TFIIF (NM_002096). NF- $\mathrm{KB}$, which is activated by ouabain and TANK, plays a role in immunity protection, anti-inflammation, vasomotion and cell proliferation by regulating some cytokine genes and triggering endothelial cells to secrete cytokines ${ }^{[15,16]}$. The results of the present study implied that NF- $\mathrm{\kappa B}$ was activated. The arrestin beta 1 gene (NM_004041) was upregulated in the mRNA profiles analysis. Members of the arrestin/beta-arrestin protein family are thought to participate in agonist-mediated desensitization of G-protein-coupled receptors and cause specific dampening of cellular responses to stimuli, such as hormones, neurotransmitters, or sensory signals. Arrestin beta 1 is a cytosolic protein that acts as a cofactor in the beta-adrenergic receptor kinase-mediated desensitization of beta-adrenergic receptors ${ }^{[17]}$. Physiological ouabain might be a beta-adrenergic receptor inhibitor according to upregulation of the arrestin beta 1 gene, which was proved by the downregulation $(\mathrm{Cy} 5 / \mathrm{Cy} 3=0.374)$ of the beta 2 -adrenergic receptor kinase (ADRBK2) found in the present study.

$K C N D 2$, which was found to be upregulated in the present study, is related to the potassium current, and ouabain is an inhibitor of sodium pumps. Therefore, in the present paper, we only focused on $K C N D 2$. Voltage-gated potassium (Kv) channels, which induce outward $\mathrm{K}^{+}$ion currents, are the most complex class of voltage-gated ion channels with respect to both functional and structural aspects ${ }^{[16]}$. They consist of 4 sequence-related potassium channel proteins: shaker, shaw, shab and shal, which are encoded by KCNA, KCNB, KCNC and KCND, respectively. Their diverse functions include regulation of neurotransmitter release, heart rate, insulin secretion, neuronal excitability, epithelial electrolyte transport, smooth muscle contraction, and cell volume ${ }^{[18]}$. $\mathrm{Kv} 4.2 / \mathrm{Kv} 4.3$, which are related to the shal subfamily encoded by $K C N D$, participate in the formation of transient outward $\mathrm{K}^{+}$ion current $\left(I_{\mathrm{to}}\right)$, are expressed in the epicardium of the atrium and ventricles, and create the action potential repolarization I phase.

$\mathrm{Kv}$ channels control action potential repolarization, membrane potential, and action potential frequency in excitable cells. The gene chip findings of the present study showed that KCND was upregulated HUVEC after treatment with ouabain. The SBP of OS rats treated with ouabain increased, the aortic endothelium became structurally damaged, and the expression level of Kv4.2 was higher than that of the control group ${ }^{[19]}$. The pressure, the structure of the aortic endothelium, and the Kv4.2 expression level did not change in OR rats compared with the control group. The findings indicated that endothelial cells had Kv4.2 channels encoded by $K C N D 2$, which is involved in the cell functions related to regulating ion transport in the cells. Expression of the Kv4.2 channel was upregulated after chronic treatment with ouabain, which might induce changes in the potassium concentration inside and outside cells, and then indirectly inhibit the sodium pump of the membrane. The relationship between Kv4.2 expression, pressure increases and endothelium damage indicate that $\mathrm{Kv}$ channels might be a prominent factor in the pathological process whereby ouabain induces hypertension vascular remodeling.

The results of the present study suggest that ouabain might be involved in controlling the growth and metabolism of vascular endothelium cells at physiological concentrations, but at pathological concentrations it might affect the structure and function of endothelial cells, and trigger vascular remodeling in hypertension. Nonetheless, some questions require further study, for example why ouabain was able to stimulate proliferation at a concentration of 10 $\mathrm{nmol} / \mathrm{L}$, which is higher than that found under pathological conditions? Is there "autocrine" and "paracrine" ouabain in endothelial cells, such as occurs for other hormones (eg, rennin)? We will address these questions in future studies. 


\section{Acknowledgement}

We would like to thank all members of our ouabain study group.

\section{References}

1 Ferrandi M, Manunta P, Rivera R, Bianchi G, Ferrari P. Role of the ouabain-like factor and $\mathrm{Na}-\mathrm{K}$ pump in rat and human genetic hypertension. Clin Exp Hypertens 1998; 20: 629-39.

2 Chomczynski P, Sacchi N. Single-step method of RNA isolation by acid guanidinium thiocyanate-phenol-chloroform extraction. Anal Biochem 1987;162:156-9.

3 Schena M, Shalon D, Davis RW, Brown PO. Quantitative monitoring of gene expression patterns with a complementary DNA microarray. Science 1995; 270: 467-70.

4 Yuan CM, Manunta P, Hamlyn JM, Chen S, Bohen E, Yeun J, et al. Long-term ouabain administration produces hypertension in rats. Hypertension 1993; 22: 178-83.

5 Tipton C, Sebastian L, Overton J, Woodman CR, Williams SB. Chronic exercise and its hemodynamic influences on resting blood of hypertension rats. J Appl Physiol 1991; 71: 2206-11.

6 Hamlyn JM, Blaustein MP, Bova S, DuCharme DW, Harris DW, Mandel F, et al. Identification and characterization of a ouabain-like compound from human plasma. Proc Natl Acad Sci USA $1991 ; 88: 6259-63$.

7 Glitsch HG. Electrophysiology of the sodium-potassium-ATPase in cardiac cells. Physiol Rev 2001; 81: 1791-826.

8 Orlov SN, Thorin-Trescase N, Pchejetski D, Taurin S, Farhat N, Tremblay $\mathrm{J}$, et al. $\mathrm{Na}^{+} / \mathrm{K}^{+}$pump and endothelial cell survival: $\left[\mathrm{Na}^{+}\right]_{\mathrm{i} /}\left[\mathrm{K}^{+}\right]_{\mathrm{i}}$-independent necrosis triggered by ouabain, and protection against apoptosis mediated by elevation of $\left[\mathrm{Na}^{+}\right]_{\mathrm{i}}$. Plflugers Arch 2004; 448: 335-45.

9 Hamlyn JM, Maunta P. Ouabain, digitalis-like factors and hypertension. J Hypertens 1992; 10: s99-105.
10 Xiao AY, Wei L, Xia S, Rothman S, Yu SP. Ionic mechanism of ouabain-induced concurrent apoptosis and necrosis in individual cultured cortical neurons. J Neurosci 2002; 22: 1350-62.

11 Taurin S, Seyrantepe V, Orlov SN, Tremblay TL, Thibault P, Bennett MR, et al. Proteome analysis and functional expression identify mortalin as an antiapoptotic gene induced by elevation of $\left[\mathrm{Na}^{+}\right]_{\mathrm{i}} /\left[\mathrm{K}^{+}\right]_{\mathrm{i}}$ ratio in cultured vascular smooth muscle cells. Circ Res 2002; 91: 915-22.

12 Deucher A, Efimova T, Eckert RL. Calcium-dependent involucrin expression is inversely regulated by protein kinase $\mathrm{C}(\mathrm{PKC})$ alpha and PKC delta. J Biol Chem 2002; 277: 17032-40.

13 Eude I, Dallot E, Ferre F, Breuiller-Fouche M. Protein kinase C alpha is required for endothelin-1-induced proliferation of human myometrial cell. Biol Reprod 2002; 66: 44-9.

14 Wang WJ, Kuo JC, Yao CC, Chen RH. DAP-kinase induces apoptosis by suppressing integrin activity and disrupting matrix survival signals. J Cell Biol 2002; 159: 169-79.

15 Chariot A, Lenardi A, Muller J, Bonif M, Brown K, Siebenlist U. Association of the adaptor TANK with the IKappa B kinase (IKK) regulator NEMO connects IKK complexes with IKK epsilon and TBK1 kinase. J Biol Chem 2002; 277: 37029-36.

$16 \mathrm{Du} \mathrm{H}$, Wang S. Nitric oxide and early inflammatory injury in silicosis. Wei Sheng Yan Jiu 2003; 32: 164-6. Chinese.

17 Braun L, Chiristophe T, Boulay F. Phosphorylation of key serine residues is required for internalization of the complement $5 \mathrm{a}(\mathrm{C} 5 \mathrm{a})$ anaphytoxin receptor via a beta-arrestin, dynamin, and clathrin-dependent pathway. J Biol Chem 2003; 278: 4277-85.

18 Zhu XR, Wulf A, Schwarz M, Isbrandt D, Pongs O. Characterization of human Kv4.2 mediating a rapidly-inactivating transient voltage-sensitive $\mathrm{K}^{+}$current. Receptors Channels 1999; 6: 387400 .

19 Tian G, Dang CX, Lu ZR. The change and significance of the $\mathrm{Na}^{+}-\mathrm{K}^{+}$-ATPase $\alpha$-subunit in ouabain-hypertensive rats. Hypertens Res 2001; 24: 729-35. 